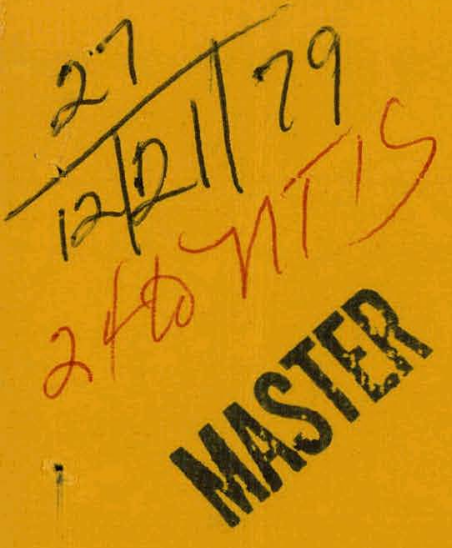

\title{
Air Quality Impacts of a Coal-Fired Power Plant in the Upper Cook Inlet of Alaska
}

November 1979

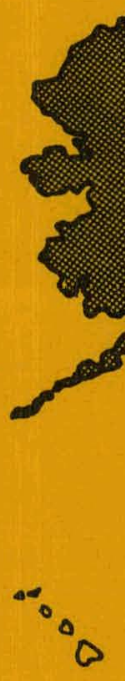

Prepared for the

U.S. Department of Energy Assistant Secretary for Environment Office of Technology Impacts under Contract EY-76-C-06-1830

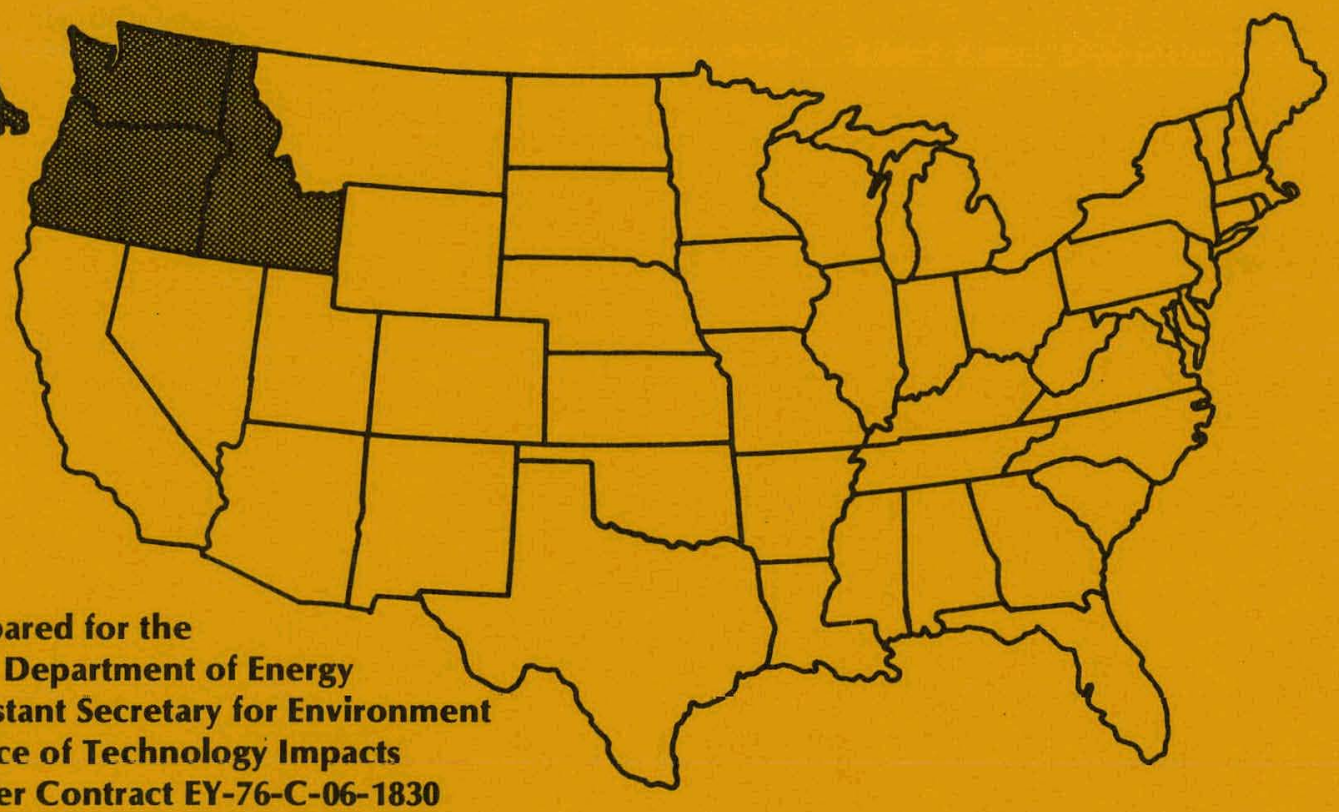

Dr. Arnold Goldberg, Project Monitor

Pacific Northwest Laboratory

Operated for the U.S. Department of Energy by Battelle Memorial Institute 


\section{DISCLAIMER}

This report was prepared as an account of work sponsored by an agency of the United States Government. Neither the United States Government nor any agency Thereof, nor any of their employees, makes any warranty, express or implied, or assumes any legal liability or responsibility for the accuracy, completeness, or usefulness of any information, apparatus, product, or process disclosed, or represents that its use would not infringe privately owned rights. Reference herein to any specific commercial product, process, or service by trade name, trademark, manufacturer, or otherwise does not necessarily constitute or imply its endorsement, recommendation, or favoring by the United States Government or any agency thereof. The views and opinions of authors expressed herein do not necessarily state or reflect those of the United States Government or any agency thereof. 


\section{DISCLAIMER}

Portions of this document may be illegible in electronic image products. Images are produced from the best available original document. 


\title{
NOTICE
}

This report was prepared as an account of work sponsored by the United States Government. Neither the United States nor the Department of Energy, nor any of their employees, nor any of their contractors, subcontractors, or their employees, makes any warranty, express or implied, or assumes any legai liability or responsibility for the accuracy, completeness or usefulness of any information, apparatus, product or process disclosed, or represents that its use would not infringe privately owned rights.

The views, opinions and conclusions contained in this repert are those of the contractor and do not necessarily represent those of the United States Government or the United States Department of Energy.

\author{
PACIFIC NORTHWEST LABORATORY \\ operated by \\ BATTELLE \\ for the \\ UNITED STATES DEPARTMENT OF ENERGY \\ Under Contract EY-76-C-06-1830
}

\begin{tabular}{|c|c|}
\hline \multicolumn{2}{|c|}{$\begin{array}{l}\text { Printed in the United States of America } \\
\text { Available from } \\
\text { National Technical information Service } \\
\text { United States Department of Commerce } \\
5285 \text { Port Royal Road } \\
\text { Springfield, Virginia 22151 }\end{array}$} \\
\hline ice: Printed Cop) & $\therefore$ Microfiche $\$ 3.00$ \\
\hline - Pages & $\begin{array}{c}\text { NTIS } \\
\text { Selling Price }\end{array}$ \\
\hline $001-025$ & $\$ 4.00$ \\
\hline $026-050$ & $\$ 4.50$ \\
\hline US $1-U / S$ & 35.25 \\
\hline $076-100$ & $\$ 6.00$ \\
\hline $101-125$ & $\$ 6.50$ \\
\hline $126-150$ & 57.25 \\
\hline $151-175$ & $\$ 8.00$ \\
\hline $176-200$ & $\$ 9.00$ \\
\hline $201-225$ & 59.25 \\
\hline $226-250$ & $\$ 9.50$ \\
\hline $251-275$ & $\$ 10.75$ \\
\hline $276-300$ & $\$ 11.00$ \\
\hline
\end{tabular}


AIR QUALITY IMPACTS OF A COAL-FIRED POWER PLANT IN THE UPPER COOK INLET OF ALASKA

Prepared for the

U.S. Department of Energy

Ass istant Secretary for Environment

Office of Technology Impacts

under Contract EY-76-C-06-1830

Dr. Arnold Goldberg, Project Monitor

Technology Assessment Division

Prepared by Daniel J. McNaughton

November 1979

This book was prepared as an account of mork sponsored by an agency of the United States Government. Neither the United States Government nor any anency thereof, not any of their emplowees, makes any warranty, express or intuled, of any information. epparatus, product, or process discilosed. of

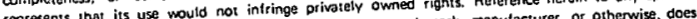
commercial product. process, or service by trade name, irademark, manutsectures, or oh by the United nor necessarily constitute or imply its endorsement. recommendat suthors expressed herain do not Siates Government of anv apency thereot. The views sove opment or any agency thereof.

Pacific Northwest Laboratory Richland, Washington 99352 
THIS PAGE

WAS INTENTIONALLY

LEFT BLANK 


\section{SUMMARY AND ACKNOWLEDGMENTS}

Air quality impacts for a proposed 500-MWe power plant in the Upper Cook Inlet are analyzed using screening-level models as a means to study coal development in Alaska. Simulation cases were run that examined impacts of controls on sulfur dioxide emissions. Results indicated that the highest concentrations of sulfur dioxide occur for the uncontrolled case whereas lower plume rise causes maximum concentrations of nitrogen dioxide and total suspended particulates when sulfur dioxide emissions controls reduce plume rise. Plume interactions with terrain result in maximum plant impacts and indicate a sensitivity of results to plant location.

Analysis of visibility degradation and sulfate formation indicated small plant impacts on the Cook Inlet.

The generic plant simulated at Beluga would be in compliance with federal and state standards when sulfur dioxide. emissions are controlled but would exceed prevention of significant deterioration (PSD) increments for sulfur dioxide if emissions are not controlled, which would indicate, when model conservatism is considered, a need for further. studies if sulfur dioxide emissions were not controlled. Impacts for a plant significantly different from the generic plant in design and location would require additional study.

Research for this study was sponsored by the U.S. Department of Energy, Office of Technology Impacts, Technology Assessments Division, under Contract EY-76-C-06-1830. The author would like to thank Mr. Robert Kerns for assistance in data processing and to acknowledge helpful conversations with Mr. Robert Wilson, EPA Region $X$, and Mr. Douglas Pottratz, Washington.Water Power Company. 
THIS PAGE

WAS INTENTIONALLY

LEFT BLANK 


\section{CONTENTS}

SUMMARY AND ACKNOWLEDGMENTS

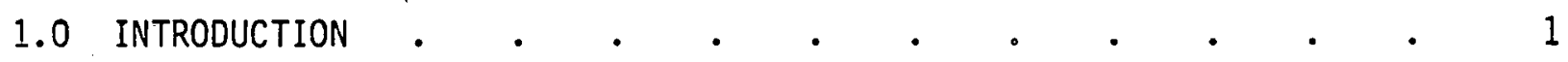

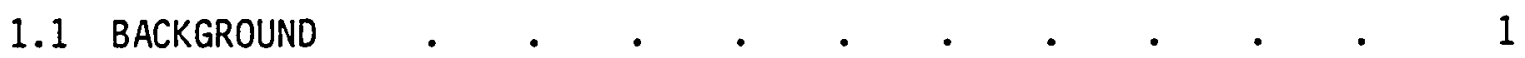

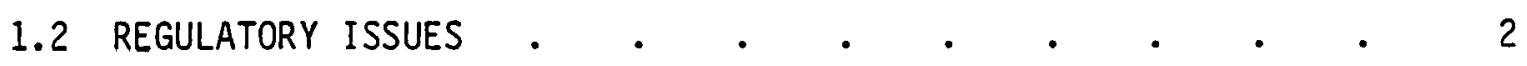

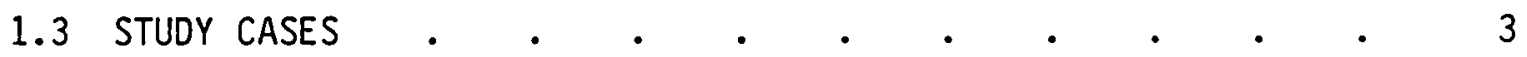

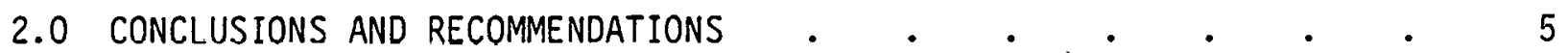

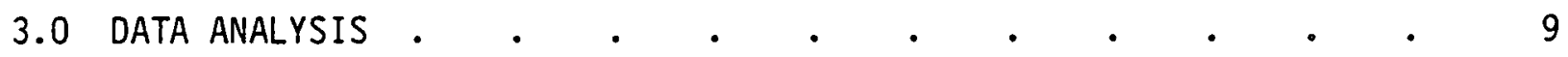

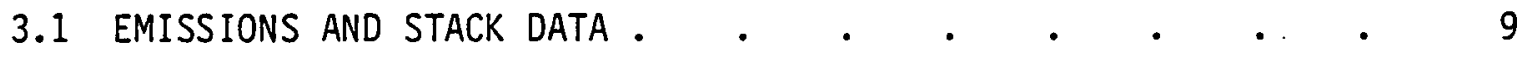

3.1 .1 Coal Firing and Stack Parameters . . . . . . 9

3.1 .2 Emissions . . . . . . . . . . . . . 10

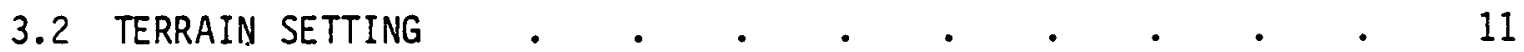

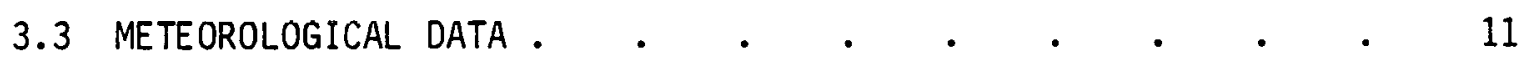

3.3.1 Climate of the Upper Cook Inlet . . . . . . 12

3.3.2 Data for Impact Analysis . . . . . . . 14

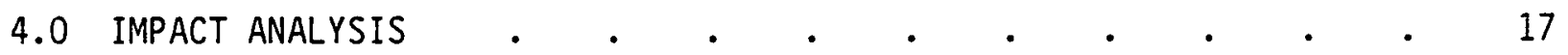

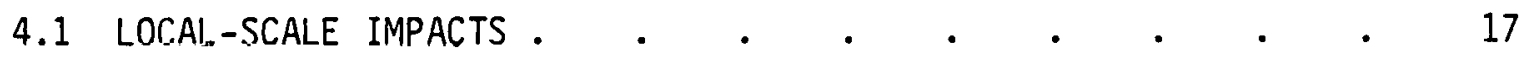

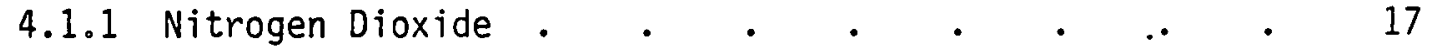

4.1.2 Sulfur Dioxide . . . . . . . . . . . 18

4.1.3 Total Suspended Particulates . . . . . . 21

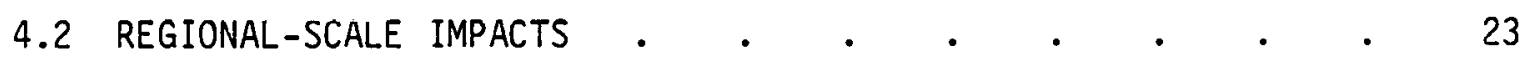

4.2 .1 Visibility . . . . . . • • . . . . 23

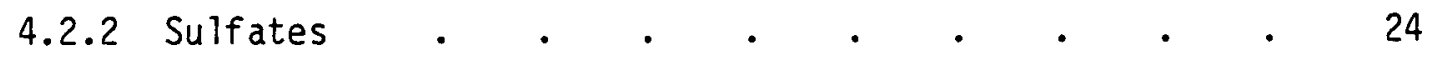

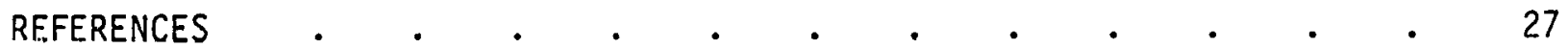

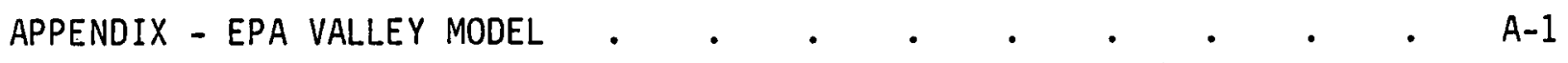




\section{FIGURES}

1 Location of the Beluga Plant and Terrain Heights Greater

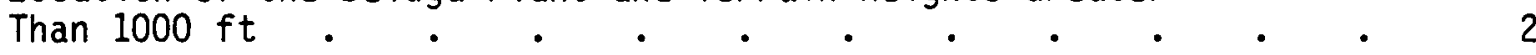

2 Terrain Profiles Used in Beluga Simulations (ft) . . . . . 12

3 Anchorage Wind Rose (1965-1969) (Broad Bars Indicate

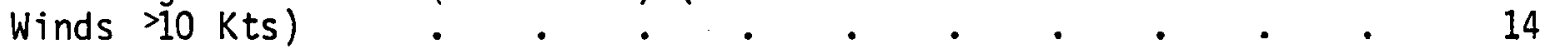

4 Beluga Wind Rose Constructed for Screening Simulations . . . 16

5 Annual Average $\mathrm{NO}_{2}$ Concentrations $\left(\mu \mathrm{g} \mathrm{m}^{-3}\right)$ for the Controlled $\mathrm{SO}_{2}$ Emtssions Simulations . . . . . . . . . 18

6 Annual Average $\mathrm{SO}_{2}$ Concentrations $\left(\mu \mathrm{g} \mathrm{m}^{-3}\right)$ for

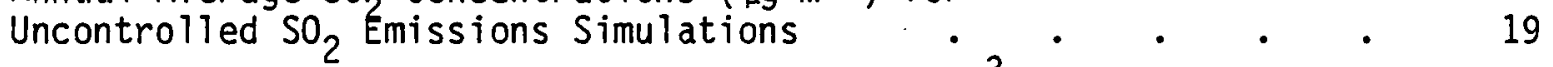

7 Maximum 24-hr Average $\mathrm{SO}_{2}$ Concentrations $\left(\mu \mathrm{g} \mathrm{m}^{-3}\right) \quad$. . . . 20

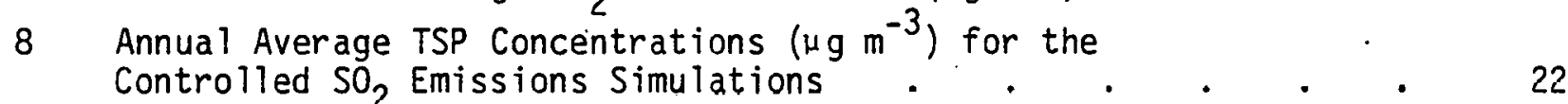

9 Maximum 24-hr TSP Concentrations $\left(\mu \mathrm{g} \mathrm{m}^{-3}\right) \quad$ • $\quad . \quad$. $\quad . \quad$ • 23 


\section{TABLES}

1 National and Alaska Ambient Air Quality Standards $\left(\mu \mathrm{g} \mathrm{m}^{-3}\right) \quad$ - 4

2 Increments for the Prevention of Significant Deterioration of Air Quality for Class II Areas . . . . . . . . . . 4

3 Power Plant Stack and Operating Parameters . . . . . . 10

4 Power Plant Emissions $\left(\mathrm{g} \mathrm{s}^{-1}\right) \quad$. $\quad . \quad . \quad . \quad . \quad . \quad . \quad 11$

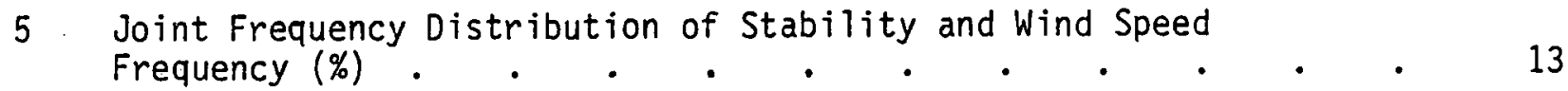

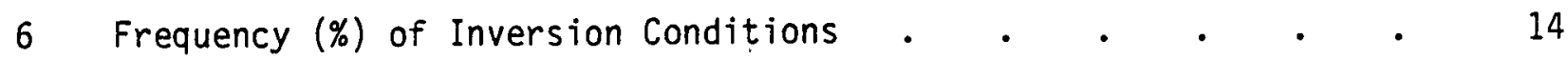

7 Sulfur Dioxide 3-hr Average Maximum Concentrations . • • 21

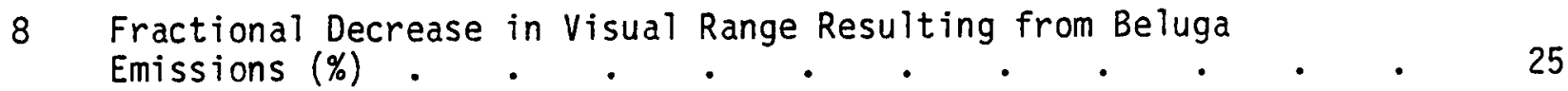




\subsection{INTRODUCTION}

The Beluga area in the Upper Cook Inlet area of Alaska has been identified as a candidate site for a coal-fired electrical generating facility (Burnham 1977). The Inlet region is abundant with low-sulfur coal and is located near the Anchorage metropolitan area. This report presents results of an analysis of the air quality impacts of siting a 500-MWe power plant at Beluga.

\subsection{BACKGROUND}

Proposed mining of the Beluga coal fields would provide an abundant supply of low-sulfur coal that could be used in power generation for Anchorage, or for both Anchorage and Fairbanks should an intertie be completed between these load centers. One important constraint on construction of a coal-fired power plant is the maintenance of air quality in the air shed of the plant, which is gauged by emissions regulations and ambient air quality standards. New regulations by the Environmental Protection Agency (EPA) require simulations of plant impacts as a condition for permitting plant construction. The simulation procedure (EPA 1978) follows a decision-tree approach whereby the proposed plant is first simulated with conservative air quality models and existing or assumed data representing the dispersion potential of an area. If this "screening" procedure indicates minimal impacts, a permit is issued; if it does not, further analysis requiring more sophisticated models and/or meteorological monitoring is required. This study represents a "screening" investigation of the air quality impacts of a hypothetical 500-MWe power plant at Beluga. The lack of good site-specific meteorolngical data limits the analysis to this "screening" level.

The following subsections describe the primary regulations of concern in new emission-source construction and the cases selected for simulation. Section 2.0 presents conclusions and recommendations. Section 3.0 describes mode 1 inputs including the plant emissions and stack parameters, meteorological data, and the terrain setting of the proposed plant. The study assumes plant siting near an existing generating facility at Beluga in the flat basin north of the inlet (Figure 1). Location of a plant in the terrain farther west of Beluga 


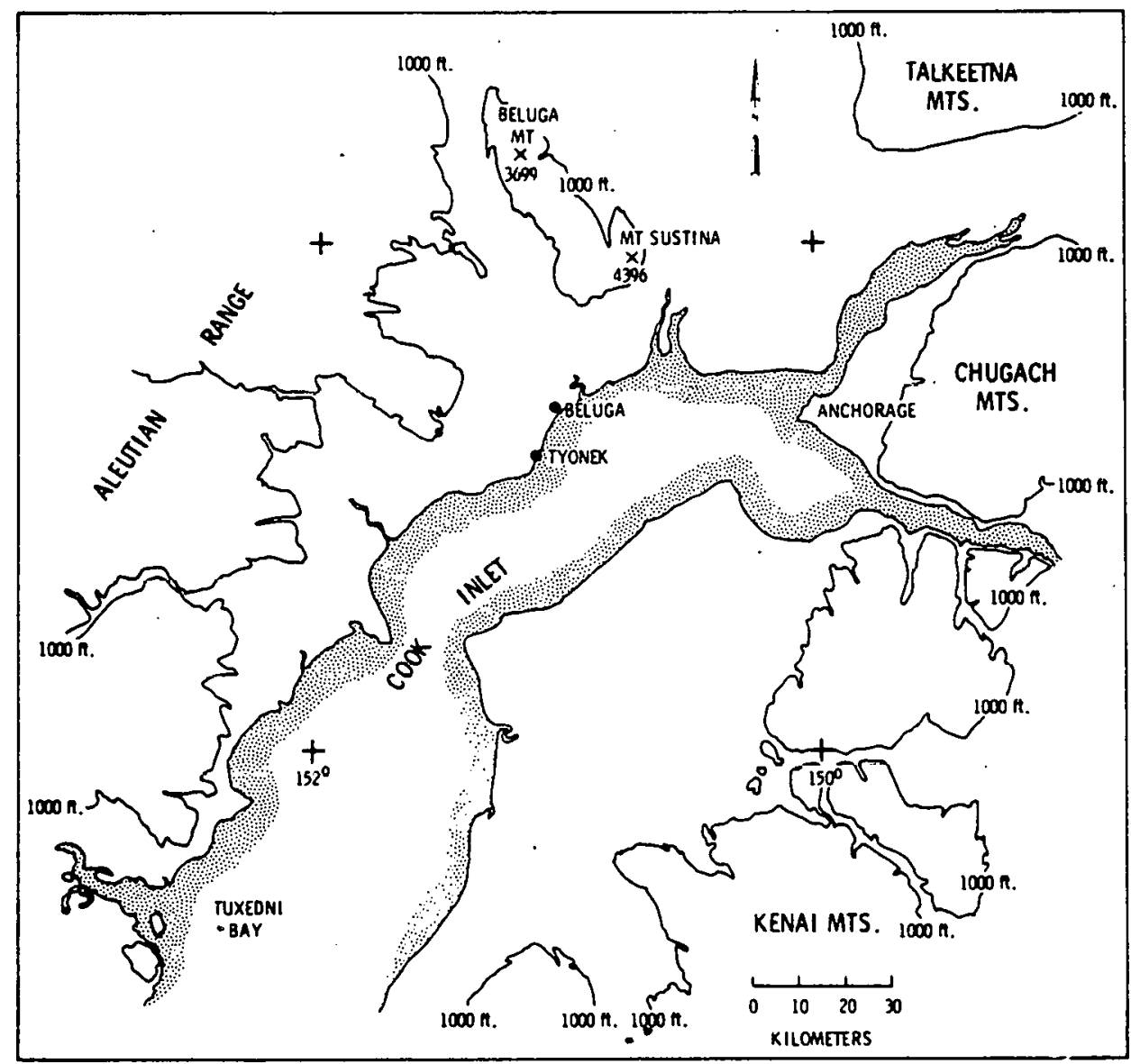

FIGURE 1. Location of the Beluga Plant and Terrain Heights Greater Than $1000 \mathrm{Ft}$

could potentially cause adverse air quality impacts as a result of plume interaction with the terrain. Section 4.0 provides results of the local plant. impacts $(0$ to $30 \mathrm{~km}$ ) and regional impacts of the plant on the Upper Cook Inlet.

\subsection{REGULATORY ISSUES}

Construction of a new power plant in the Upper Cook Inlet would require compliance with the EPA New Source Performance Standards (NSPS) for emissions, the National and Alaska Ambient Air Quality Standards (NAAQS, AAAQS), and the standards for the prevention of significant deterioration (PSD) of air quality. Applicable emissions regulations under NSPS are as follows:

- $\mathrm{SO}_{2}-70 \%$ control of emissions with maximum emissions at 1.2 lb per $10^{6}$ BTU heat input 
- Particulates - 0.03 lb per $10^{6}$ BTU heat input

- Nitrogen oxides (as $\mathrm{NO}_{2}$ ) -0.5 lb per $10^{6}$ BTU heat input

Sulfur dioxide scrubbing, as required, is a highly controversial issue because of expense and sludge disposal problems. This problem is particularly true in the western United States where combustion of low-sulfur coals results in uncontrolled emissions lower than the maximum allowable.

Table 1 presents a list of National and Alaska Ambient Air Quality Standards. Differences in state and national standards exist only in the more stringent Alaska total suspended particulate (TSP) standard. The national TSP standard may be changed in the near future as research defines a means of separating the fugitive dust and large particles from the respirable particle components of total suspended particles in both monitoring and in impact analysis.

Regulations governing the PSD serve to prevent increases in pollutant concentrations above an increment determined by existing pollutant loading of an area. The Upper cook Inlet has been classified as a Class II area and new emission sources must comply with the increments $(a)$ in Table?. The nearest Class I area where more stringent increments would be applied is located at Tuxedni Bay over $100 \mathrm{~km}$ south-southwest of Beluga which is beyond the impact area of the plant.

\subsection{STUDY CASES}

Simulations for the dispersion of sulfur dioxide $\left(\mathrm{SO}_{2}\right)$, particulate, and nitrogen oxide (as $\mathrm{NO}_{2}$ ) emissions for the Beluga plant were carried out for each of the time periods in Table 1. To account for uncertainties in the application of the New Source Performance Standards and to provide an assessment of the impact of those standards in Alaska, two simulations were run for each pollutant and averaging time. The first case represents the impacts of combustion of Beluga coal without $\mathrm{SO}_{2}$ controls whereas the second case represents controlled. $\mathrm{SO}_{2}$ and the accompanying decrease in flue gas volume and exit temperature.

(a) The Clean Air Act as amended August, 1977. Serial No. 95-11, U.S. Government Printing Office, Washington, 1977. 
TABLE 1. National and Alaska Ambient Air Quality Standards ( $\mu \mathrm{g} \mathrm{m}^{-3}$ )

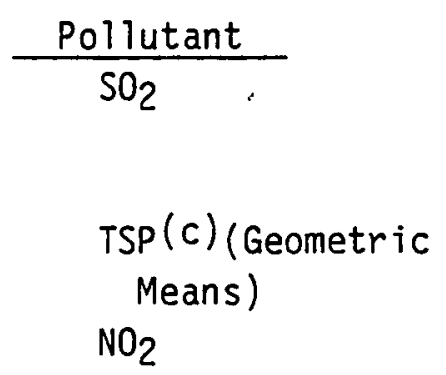

\section{Averaging}

$\frac{\text { Period }}{\text { Annual }}$

24-hr

3-hr

Annua $]$

24-hr

Annual
Maximum Al lowable Increase $\left(\mu \mathrm{g} \mathrm{m}^{-3}\right)$

\begin{tabular}{|c|c|}
\hline National (a) & Alaska(b) \\
\hline 80 & 80 \\
\hline 365 & 365 \\
\hline 1300 & 1300 \\
\hline 75 & 60 \\
\hline 260 & 150 \\
\hline 100 & 100 \\
\hline
\end{tabular}

(a) Federal Register, 36 (84), 8186-8222, April 30, 1971

(b) Personal Communication, Alaska Department of Environmental Conservation

(c) Total suspended particulate

TABLE 2. Increments for the Prevention of Significant Deterioration of Air Quality for Class II Areas

\begin{tabular}{|c|c|c|}
\hline Pollutant & $\begin{array}{l}\text { Averaging } \\
\text { Period } \\
\end{array}$ & $\begin{array}{l}\text { Maximum Allowable } \\
\text { Increase }\left(\mathrm{\mu g} \mathrm{m}^{-3}\right)\end{array}$ \\
\hline \multirow[t]{3}{*}{$\mathrm{SO}_{2}$} & Annual & 20 \\
\hline & $24-h r$ & 91 \\
\hline & $3-h r$ & 512 \\
\hline \multirow[t]{2}{*}{ Particles } & Annual & 19 \\
\hline & $24-h r$ & 37 \\
\hline
\end{tabular}




\subsection{CONCLUSIONS AND RECOMMENDATIONS}

An analysis of the local and regional impacts of siting a 500-MWe coal burning power plant at Beluga is presented. Data for analysis of air quality and dispersion potential in the Upper Cook Inlet of Alaska are sparse, particularly in the coal-rich area northwest of the inlet. The analysis is of the level of a "screening" study as defined by the Environmental Protection Agency (EPA) for the first phase of a permitting procedure (EPA 1978) as a result of limitations of sparse data and available plant siting and operating parameters. The main conclusion of the study is that based on current National and Alaska Ambient Air Quality Standards (AAQS), the New Source Performance Standards (NSPS) and the Prevention of Significant Deterioration (PSD) increments, construction of a plant of the design assumed at Beluga would be approved after the first or "screening" level of analysis. Comparative studies of a plant without NSPS sulfur dioxide controls indicated that such a plant would require additional analysis by more sophisticated meteorological data collection and modeling to predict plant compliance to standards.

Compliance with applicable air quality standards is demonstrated by the fraction of the standard concentrations calculated for the incremental plant impact as follows:

\begin{tabular}{|c|c|c|c|c|}
\hline \multirow{3}{*}{$\begin{array}{l}\text { Pollutant } \\
\text { Averaging } \\
\text { Period }\end{array}$} & \multicolumn{4}{|c|}{ Fraction of Standard (\%) } \\
\hline & $\mathrm{SO}_{2}$ Contr & led & $\mathrm{SO}_{2}$ UnCo & lled \\
\hline & AAQS & $\overline{P S D}$ & $\mathrm{AAQS}$ & $\overline{P S D}$ \\
\hline $\mathrm{SO}_{2} 3-\mathrm{hr}$ & 30 & $\overline{77}$ & 56 & $\overline{142}$ \\
\hline $24-h r$ & 18 & 73 & 50 & 200 \\
\hline Annual & 6 & 24 & 17 & 67 \\
\hline TSP $24-h r$ & $7(4)^{(b)}$ & 29 & $6(3)$ & 24 \\
\hline Annual & $17(14)$ & 54 & $1(1)$ & 5 \\
\hline $\mathrm{NO}$, Annual & 16 & (a) & 14 & (a) \\
\hline
\end{tabular}

(a) No PSD increment

(b) National Ambient Air Quality Standard comparison given in parenthesis 
The most sensitive conditions for compliance are the 3-hr and 24-hr average impacts caused by the interaction of the plume and terrain north and west of Beluga. If $\mathrm{SO}_{2}$ emissions were uncontrolled, the "screening" analysis does not show compliance with the PSD increments, although more sophisticated studies might.

Current air quality in the Upper Cook Inlet is good except for problems with fugitive dust, mainly of natural origin, which is particularly prevalent in the summer months. The $24-h r$ average TSP concentration is currently exceeded in the Inlet area, but particulate loading by the Beluga plant would not appear to contribute significantly to this problem.

The terrain influence of the mountains surrounding the inlet would require that additional analyses be performed if another plant site were selected. Maximum Beluga plant impacts as simulated are in mountains north and west of the plant, and local-scale results are very sensitive to location.

Plant impact studies presented were made with a conservative screening model, and therefore, plant siting at Beluga would appear feasible based on predicted air quality. Plant configurations and locations other than those studied may be equally favorable but more sophisticated studies may be required as confirmation since results are sensitive to siting relative to the local terrain.

Regional-scale impacts studied include formation of sulfate particles and visibility impairment by these particles. Results indicate that at $100 \mathrm{~km}, \mathrm{a}$ characteristic half-width of the Cook Inlet, visual range could be decreased a maximum of approximately $4 \%$ if $\mathrm{SO}_{2}$ emissions were controlled $70 \%$, or approximately $11 \%$ if $\mathrm{SO}_{2}$ emissions were uncontrolled. Predictions of sulfate concentration or any secondary pollutant would require more detailed data on airflow throughout the Cook Inlet air shed. Simplified estimates of annual and 24-hr average sulfate concentrations were made using an exponential decay/conversion of $\mathrm{SO}_{2}$ to sulfate at a rate of $0.5 \% \mathrm{hr}^{-1}$ and no deposition of $\mathrm{SO}_{2}$ and sulfate from the plume. Results showed that concentrations would be undetectable on an annual basis and approximately $0.1 \mu \mathrm{g} \mathrm{m}^{3}$. for a 24-hr concentration out to distances of $100 \mathrm{~km}$ from the plant. These values are extremely low when compared to concentrations contributing to acid rains in areas such as the Northeast of the United States. 
Results of the analysis suggest the need for the following:

- A formal screening analysis as part of the permit application procedure when a site and plant design are finalized.

- A meteorological monitoring program and sophisticated modeling study if expected plant size is significantly larger than 500 MWe or if the plant site is moved closer to the mountains north or west of the plant.

- An evaluation of data requirements should new standards for small particles or visibility be established

- A determination of the attitudes of the local air quality agencies and EPA on new emission source construction at locations with a history of TSP standard excursions as a result of fugitive dust. 
THIS PAGE

WAS INTENTIONALLY

LEFT BLANK 


\subsection{DATA ANALYSIS}

Impact assessment for power development requires an in-depth understanding of the proposed power plant project and site-specific descriptions of plant environment that consider terrain and dispersion potential. This section provides a description and analysis of a hypothetical power plant sited at Beluga, the terrain setting of the plant, and the meteorological data available to assess plant impacts. The selection of data for simulations is also described.

\subsection{EMISSIONS AND STACK DATA}

The impacts of coal-based electrical generation in the upper Cook Inlet are simulated using a single 500-MWe power plant located at Beluga. It was assumed that the hypothetical plant would consist of 2 to 250 MWe units breeched to a single stack. Prevention of Significant Deterioration regulations and the New Source Performance Standards have a profound effect on the selection of representative stack and emission parameters particularly in regard to "good engineering practice" stack heights and flue gas scrubbing for $\mathrm{SO}_{2}$ removal. This subsection section describes data and assumptions leading to development of a representative hypothetical plant data set for cases with and without flue gas desulfurization.

\subsubsection{Coal Firing and Stack Parameters}

The typical or generic power plant is difficult to define since its design is a function of fuel, regulation, required power output and other factors. The generic 500-MWe plant used for Beluga studies has an assumed plant efficiency of $40 \%$ with an additional $3 \%$ of power required for scrubber operation and flue gas reheat (Rosenberg et a1. 1975). The heating value of the coal from the Beluga Coal Project seams was assumed to be 7500 BTU $1 b^{-1}$ (PacerAmex 1977). Calculated values for the peak-load firing rate and flue gas rate (assuming 15\% excess air) are given in Table 3.

Stack helght for the generic power plant (Table 3) was selected by assuming a plant superstructure of $200 \mathrm{ft}$ and calculating stack height based on "good engineering practice" as defined in the Clean Air Act, which has been 
TABLE 3. Power Plant Stack and Operating Parameters

\begin{tabular}{|c|c|}
\hline Parameter & Value \\
\hline Capacity & 2 to 250 MWe units \\
\hline Efficiency & $40 \%$ \\
\hline Scrubber Heat Requirement & $3 \%$ \\
\hline Scrubber Efficiency & $70 \%$ \\
\hline Excess Air & $15 \%$ \\
\hline Firing Rate (Peak load) & $293 \mathrm{t} \mathrm{hr}^{-1}$ \\
\hline \multicolumn{2}{|l|}{ Exit Temperature: } \\
\hline Scrubbed & $355^{\circ} \mathrm{K}$ \\
\hline Unscrubbed & $422^{\circ} \mathrm{K}$ \\
\hline \multicolumn{2}{|l|}{ Fuel Gas Rate: } \\
\hline Scrubbed & $642 \mathrm{~m}^{3} \mathrm{~s}^{-1}$ \\
\hline Unscrubbed & $741 \mathrm{~m}^{3} \mathrm{~s}^{-1}$ \\
\hline Stack Height & $150 \mathrm{~m}$ \\
\hline Stack Diameter & $6.7 \mathrm{~m}$ \\
\hline
\end{tabular}

interpreted as 2.5 times the building height. Stack diameter was calculated from the flue gas rate assuming an exit velocity of $60 \mathrm{ft} \mathrm{s}^{-1}$.

\subsubsection{Emissions}

Emissions for $\mathrm{SO}_{2}, \mathrm{NO}_{x}$ (as $\mathrm{NO}_{2}$ ) and particles were calculated based on permissible levels given in the New Source Performance Standards (Costle 1979). Values calculated are presented in Table 4, which gives both peak-load emissions and annual average rates that were assumed to be $75 \%$ of full-load rates.

Regulations for $\mathrm{NO}_{x}$ and particles are based on $\mathrm{plant}$ heat input whereas the $\mathrm{SO}_{2}$ regulation is based on heat input to obtain the absolute limit but requires an additional factor representing emissions reduction by scrubbing. Two cases presented examine emissions from a plant burning Beluga coal: 1) uncontrolled $\mathrm{SO}_{2}$ emissions and 2) $\mathrm{SO}_{2}$ emissions controlled $70 \%$. 
TABLE 4. Power Plant Emissions $\left(\mathrm{g} \mathrm{s}^{-1}\right)$

Emissions Peak Load Annual Load

Sulfur Dioxide:

- Uncontrolled $266^{(a)}$ 199

- Controlled 80

Particulate

Nitrogen Dioxide

277

208

(a) Sulfur content of coal $0.18 \% \mathrm{~S}$ (Pacer-Amex 1977)

\subsection{TERRAIN SETTING}

Impacts of an emission source are strongly influenced by terrain both 1) in its modification of stability and wind regimes (e.g., drainage wind and channeling), and 2) as a possible impact area at or above source plume height. The terrain setting of the Beluga area is presented in Figure 1 . The northern part of the Cook Inlet is surrounded by the Chugach Mountains on the east, Talkeetna Mountains on the north and the Alaska Range on the West. The location of Beluga on the Cook Inlet results in near sea-level elevations in directions north-northeast clockwise through south of Beluga to at least $30 \mathrm{~km}$ from the town. The most significant terrain features are the shoreline, which causes a transition zone in the boundary layer, and higher terrain north and west of the town. Twenty-five to $30 \mathrm{~km}$ west and northwest of Beluga the terrain rises to 1500 and $2000 \mathrm{ft}$. Elevations of greater than $500 \mathrm{ft}$ do not occur within $12 \mathrm{~km}$ of Beluga.

Terrain heights used in simulations are given in Figure 2. Since the exact plant location is not known, the terrain profiles were selected by choosing the highest elevation in 5-km sections along each downwind radial for which receptors were selected.

\subsection{METEOROLOGICAL DATA}

The largely undeveloped state of the western shore of the Cook Inlet has resulted in a lack of meteorological data sufficient for fine-scale dispersion studies. This section provides a brief description of climate of the Upper 


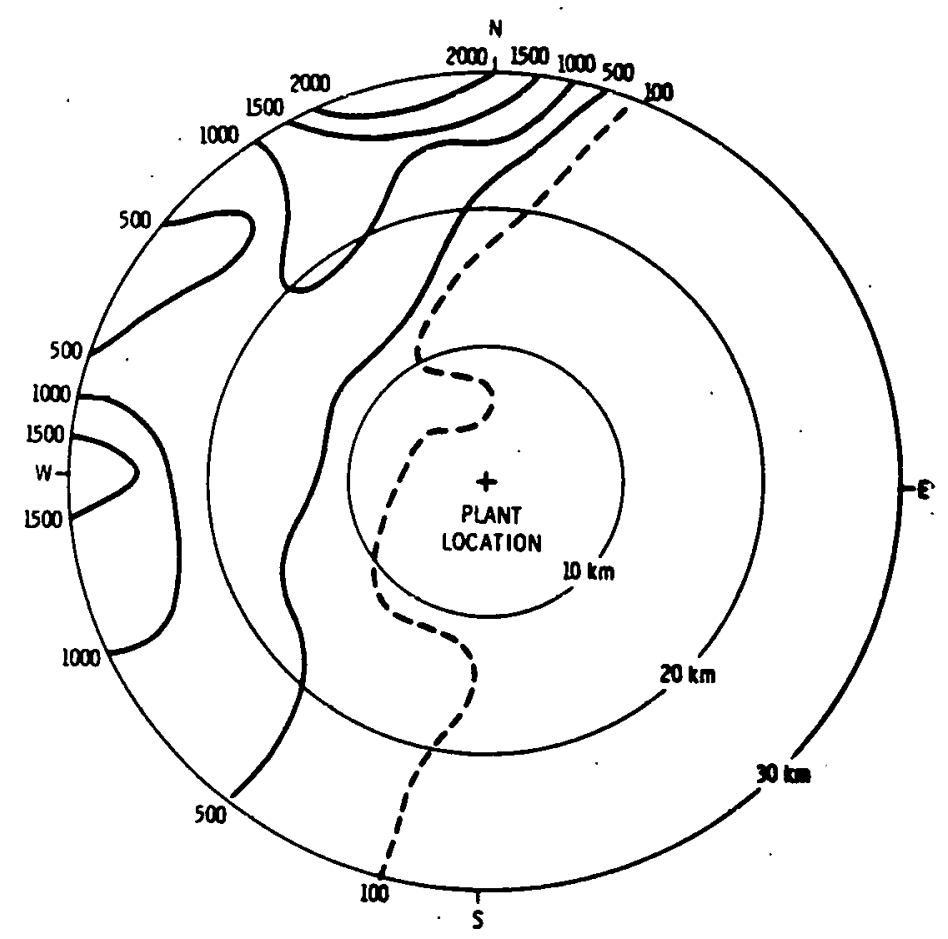

FIGURE 2. Terrain Profiles Used in Beluga Simulations (ft)

Cook Inlet and a discussion of data used for impact analysis of the Beluga power plant. These discussions are based on the sketchy data available and expected dispersion potential based on the influence of airflows in terrain and the land/sea interface shown by studies in other regions.

\subsubsection{Climate of the Upper Cook Inlet}

The Upper Cook Inlet is in a transition region of coastal maritime influences and more variable interior or continental influences (Evans 1972). Cloud cover in the region is generally uniform throughout the year with a slight increase in cloud cover occurring in the summer months. Fog, which is indicative of the influence of the Cook Inlet as a moisture source in the cold stable air layer, forms in periods of clear winter weather. Winds in the region are generally from the north during winter with occasional strong gusty winds in response to storm formation (cyclogenesis) in the Gulf of Alaska. Winds in the summer are generally from the south (Swift et al. 1974).

Because of terrain influences, local climate can be highly variable, but many characteristics of the Inlet climate can be determined by an examination 
of Anchorage data. Table 5 presents a joint frequency distribution for wind speed and atmospheric stability classes for Anchorage. The table indicates a high frequency of stable conditions (30\%) with low wind speeds that may be typical of drainage winds during periods of stagnation or light, synoptically driven winds. Forty-three percent of winds occur under neutral conditions where wind speeds are in the range of 4 to $16 \mathrm{kts}$. These winds are primarily oriented in the north and south directions reflecting large-scale flows channelled by the Chugach Mountains. Unstable conditions occur approximately $17 \%$ of the time predominantly as light winds from the west through northeast. The long-term frequency distribution of wind speeds for Anchorage is given in Figure 3 .

Rawinsonde data for Anchorage have been analyzed to show the frequency of occurrence of inversions with bases within given height intervals (Table 6). The table indicates that low-level inversions occur most nights so that a plume emitted from an elevated source would normally be separated from the surface by a stable layer. During the day, the frequency of low-level stable layers is reduced with solar heating and subsequent convection from the ground. No preferred inversion base height above the surface is indicated in the data.

TABLE 5. Joint Frequency Distribution of Stability and Wind Speed Frequency (\%)

Windspeed (Kts)

\begin{tabular}{|c|c|c|c|c|c|c|c|}
\hline \multirow[b]{2}{*}{ Stability } & \\
\hline & 1 to 3 & 4 to 6 & 7 to 10 & 11 to 16 & 17 to 21 & 21 & Total \\
\hline$A$ & 0.03 & 0.00 & 0.00 & 0.00 & 0.00 & 0.00 & 0.03 \\
\hline$B$ & 2.16 & 1.59 & 0.53 & 0.00 & 0.00 & 0.00 & 4.29 \\
\hline C & 5.62 & 4.36 & 2.62 & 0.07 & 0.00 & 0.00 & 12.68 \\
\hline D & 6.9 & 19.06 & 14.04 & 10.40 & 1.97 & 0.57 & 52.96 \\
\hline$E$ & 0.00 & 7.15 & 2.03 & 0.00 & 0.00 & 0.00 & 9.18 \\
\hline$F$ & 16.30 & 4.57 & 0.00 & 0.00 & 0.00 & 0.00 & 20.87 \\
\hline Total & 31.01 & 36.73 & 19.22 & 10.47 & 1.97 & 0.57 & 100.00 \\
\hline
\end{tabular}




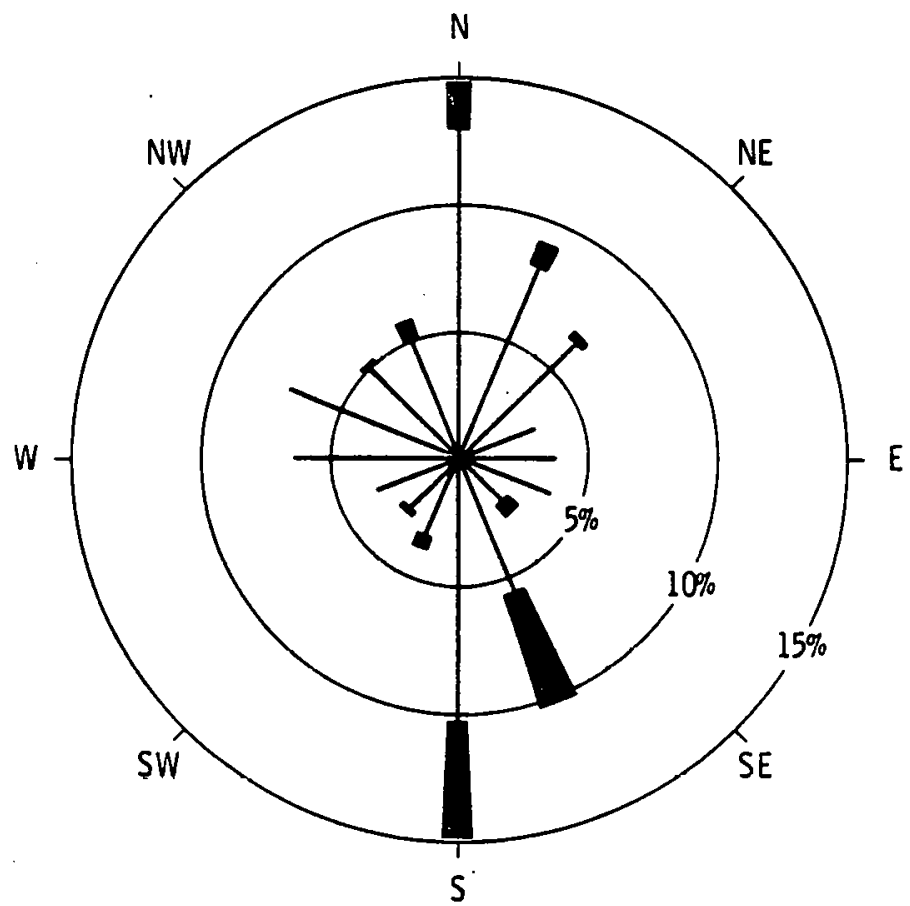

FIGURE 3. Anchorage Wind Rose (1965-1969) (Broad Bars Indicate Winds $>10 \mathrm{kts})$

TABLE 6. Frequency (\%) of Inversion Conditions

\begin{tabular}{cccc}
$\begin{array}{c}\text { Height of Inversion } \\
\text { Base }(\mathrm{m})\end{array}$ & & Morning & Night \\
\cline { 1 - 1 } $1-500$ & & 15.6 & 55.2 \\
$501-1000$ & & 19.7 & 13.3 \\
$1001-1500$ & & 8.1 & 4.6 \\
$1501-2000$ & 3.9 & 2.0 \\
$2001-2500$ & 4.7 & 1.7 \\
$2001-2500$ & 4.1 & 2.3 \\
$2501-3000$ & 3.3 & 1.3
\end{tabular}

\subsubsection{Data for Impact Analysis}

Data requirements for dispersion models commonly include site-specific, long-term records of wind speed, wind direction, and a measure of atmospheric mixing potential that ideally would include turbulence statistics but more routinely is represented by atmospheric stability classes. In addition, data 
on mixing depth or inversion frequency aid in a determination of the impacts from plumes that are trapped or capped by elevated stable layers in the atmosphere. However, because of the poor data base for the Beluga region, data for long-term assessments were obtained by modification of Anchorage data. Data for short-term impacts were selected from typical worst-case conditions for elevated emission sources.

The nearest observing station to Beluga with historical wind data is Tyonek, 10 to $15 \mathrm{~km}$ south-southwest. Data for Tyonek were collected in the early 1940's for two time periods per day with no obvious consistency in observation times for recording. The Tyonek data were qualitatively compared to the Anchorage data available for the same years but from slightly different time periods during the day. The data analysis showed no consistent or significant relationships between wind speeds, wind direction, or wind components as might be expected if the effects of synoptic-scale driving of the winds dominated the impact of local terrain effects. However, data examined from Tyonek suggested that more frequent westerly winds could be expected on the west side of the inlet because of drainage and channeling by the east-west orientation of valleys in the Aleutian Range than would be expected at Anchorage. The Anchorage wind rose is more influenced by the effects of the Kenai and Chugach Mountains located on a line slightly east of the city. In addition, the location of Tyonek and Beluga would suggest a more broad distribution of predominant southerly and northerly winds than at Anchorage because of the increased distance between these sites and the mountains.

Increased cloud cover on the west side of the inlet (Evans 1972) would tend to moderate Anchorage stability data, resulting in more frequent neutral conditions and less frequent unstable and stable conditions. Wind speeds at Tyonek and Beluga are stronger than Anchorage as a result of a more exposed location on the Inlet (Evans 1972). Increased average wind speed also tends to increase the frequency of neutral stability conditions.

A stability wind rose for Beluga was constructed using the Anchorage wind rose (Figure 3 ) as a base. The distribution of stability conditions at Anchorage was maintained since the degree of increased neutral conditions was not indicated. Likewise, expected increased wind speeds were not included in this modified stability wind rose. Higher frequencies of stable and unstable 
conditions are expected to result in a more conservative estimate of long-term concentrations. The frequencies of wind directions in each stability and wind speed class in the Anchorage wind rose were modifed by the following:

- Wind frequencies under neutral conditions were given a more westerly and southwesterly orientation.

- Under stable conditions, easterly frequency peaks were smoothed out and their frequency peaks shifted to represent broad westerly drainage winds.

- Under unstable conditions more frequent west winds were represented to reflect airflow and surface heating over land.

The resultant wind rose is shown in Figure 4 . It should be stated that this wind rose was included for screening analysis only and that additional meteorological measurements would be required for a more sophisticated analysis of the Beluga area.

Worst-case meteorological cases examined for short-term concentration estimates are: low to moderate wind speed stable conditions near terrain, high-wind speed neutral conditions and near-source unstable conditions with low wind speeds, and inversion trapping.

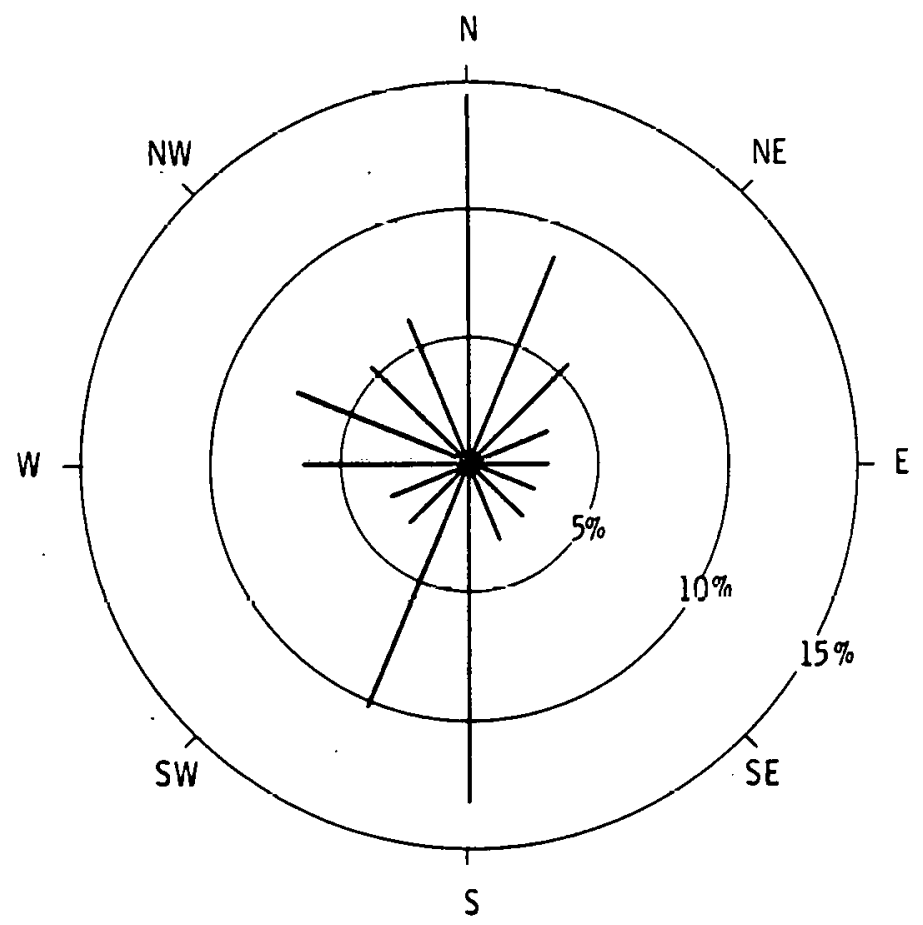

FIGURE 4. Beluga Wind Rose Constructed for Screening Simulations 


\subsection{IMPACT ANALYSIS}

The impacts of emission sources on air quality occur various time and distance scales depending on the pollutant of interest. Assessments of coalfired power plant impacts must address dispersion of the primary pollutants $\mathrm{NO}_{2}, \mathrm{SO}_{2}$ and total suspended particulates (TSP) on a local scale (0 to $50 \mathrm{~km}$ ) for averaging periods determined by regulation (See Section 1.2). On a larger regional scale (50 to $300 \mathrm{~km}$ ), the analysis must consider the effects of secondary pollutants. (a) Current interest in regional pollutant problems is focused on sulfates, because of their contribution to acid rain, and to visibility degradation by fine sulfate particles.

\subsection{LOCAL-SCALE IMPACTS}

The following subsections address compliance of the Beluga Power Plant with ambient air quality standards and significant deterioration increments for $\mathrm{NO}_{2}, \mathrm{SO}_{2}$ and TSP (Section 1.2). Results were calculated using the EPA VALLEY model, a Gaussian point-source diffusion model, for annual 24-hr and 3-hr average concentrations..

\subsubsection{Nitrogen Dioxide}

Annual average concentrations of nitrogen dioxide $\left(\mathrm{NO}_{2}\right)$ were calculated using the EPA VALLEY model for the Beluga power plant. The cases studied reflected emissions of total oxides of nitrogen expressed as $\mathrm{NO}_{2}$ for the plant operating with sulfur oxides controlled and uncontrolled.

Figure 5 presents a plot of annual average concentrations for $30 \mathrm{~km}$ around the plant. Concentrations are we 11 below the $100 \mu \mathrm{g} \mathrm{m}^{-3}$ standard and below $1 \mu \mathrm{g} \mathrm{m}^{-3}$ in all areas except in terrain west clockwise through northnortheast of the plant where a concentration peak of $16.3 \mathrm{\mu g} \mathrm{m}^{-3}$ was predicted. The peak concentration is located $20 \mathrm{~km}$ north of Beluga near Mount Susitna, which may be the most significant terrain feature for impacts in the Beluga environs. Nitrogen dioxide impacts for uncontrolled burning are less

(a) Pollutants formed from interactions involving combustion byproducts after plume release 


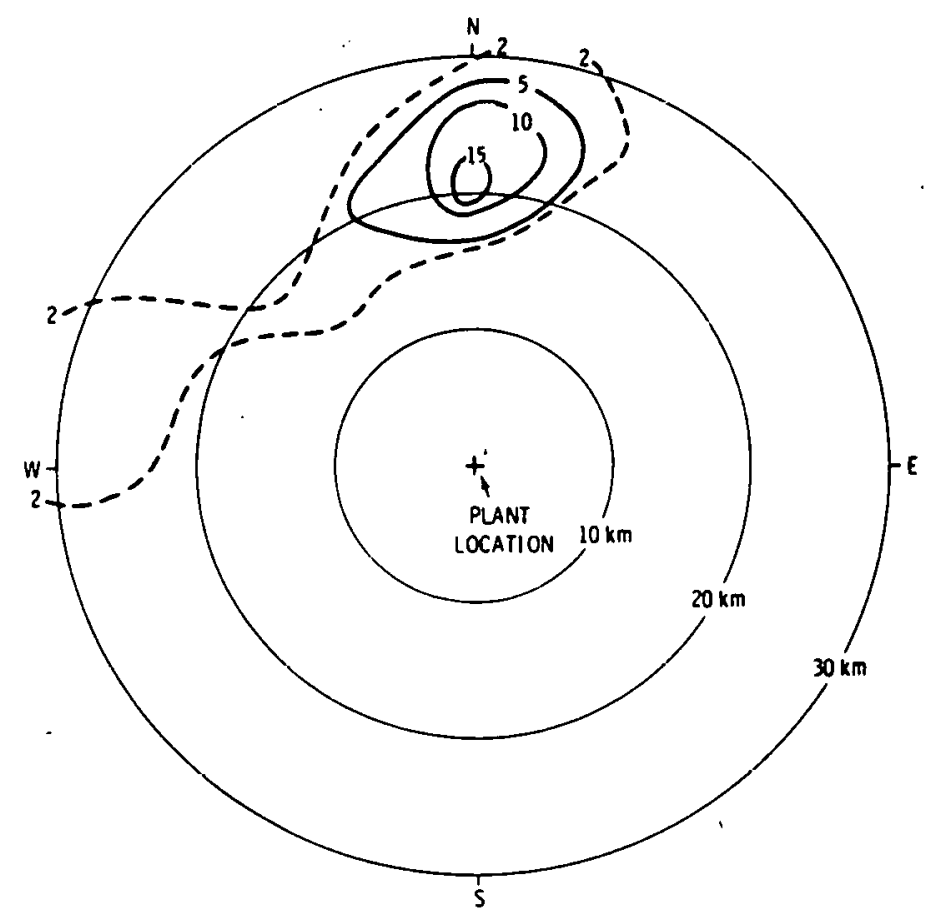

FIGURE 5. Annual Average $\mathrm{NO}_{2}$ Concentrations $\left(\mu \mathrm{g} \mathrm{m}^{-3}\right.$ ) for the Controlled $\mathrm{SO}_{2}$ Emissions Simulations

than for the controlled cases as a result of the reduced plume rise associated with scrubbing the flue gas for $\mathrm{SO}_{2}$ control. The peak concentration of $\mathrm{NO}_{2}$ for uncontrolled emissions is $14.0 \mu \mathrm{g} \mathrm{m}^{-3}$. Background $\mathrm{NO}$, concentration measurements are sparse, but a reported value of only $16 \mathrm{\mu g} \mathrm{m}^{-3}$ for Anchorage (DEC 1977) suggests that $\mathrm{NO}_{2}$ levels on an annual basis will not approach the standard.

\subsubsection{Sulfur Dioxide}

Sulfur dioxide simulation results are presented for annual, 24-hr and 3-hr averaging:

- Annual Average - Control of $\mathrm{SO}_{2}$ emissions by $70 \%$ as required by the New Source Performance Standards results in a decrease in maximum ambient concentrations from 13.4 to $4.7 \mathrm{\mu g} \mathrm{m}^{-3}$. The decrease in concentration is 1 imited to $65 \%$ because of reduced plume rise expected with flue gas scrubbing. Figure 6 shows the concentration pattern expected for uncontrolled $\mathrm{SO}_{2}$ emissions. Concentrations are greatest west and north of Beluga in the higher terrain with the highest value $20 \mathrm{~km}$ north of Beluga. Concentrations for the controlled case are similar in pattern. 


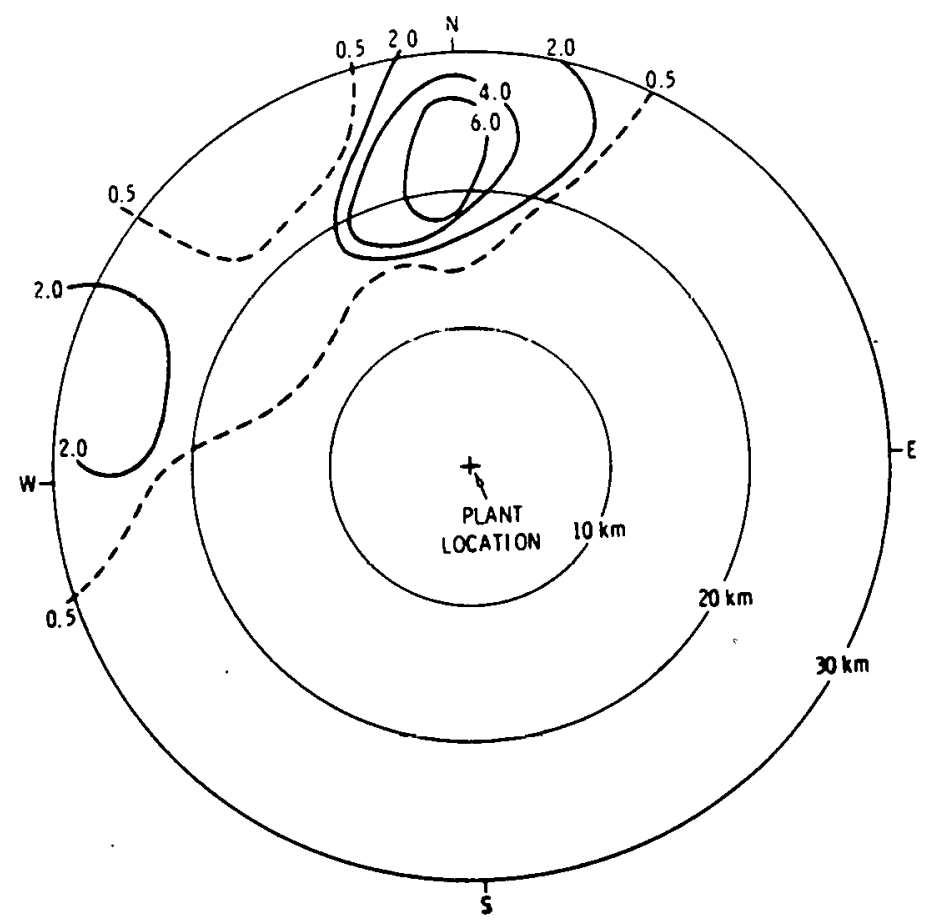

FIGURE 6. Annual Average $\mathrm{SO}_{2}$ Concentrations $\left(\mu \mathrm{g} \mathrm{m} \mathrm{m}^{-3}\right)$ Uncontrolled $\mathrm{SO}_{2}$ Emissions Simulations

Concentrations at all locations are well below the $80 \mu \mathrm{g} \mathrm{m}^{-3}$ ambient air quality standard and below the $19 \mathrm{\mu g} \mathrm{m}^{-3}$ PSD increment for Class II areas. Annual average background concentrations in the Upper Cook Inlet are typically below the minimum detection limit of sensors (DEC 1977) and contraventions of the standards are not expected.

- Twenty-four-hour Average - Figure 7, showing predicted maximum 24-hr average $\mathrm{SO}_{2}$ concentrations for the uncontrolled $\mathrm{SO}_{2}$ emission case, indi-

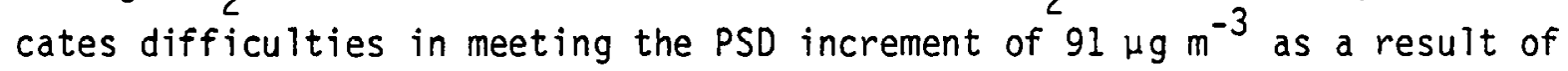
plume interaction with the terrain north of Beluga. The peak predicted concentration is $182 \mathrm{\mu g} \mathrm{m}^{-3} 20 \mathrm{~km}$ north of the plant. Results from the controlled emissions simulations are in compliance with the PSD increments with a

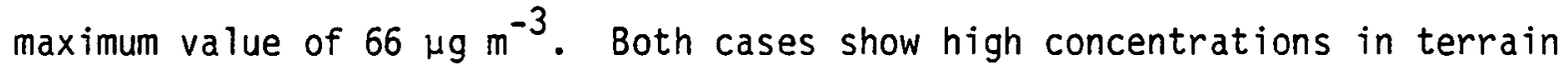
north, north-northwest and west-northwest of Beluga and, in the uncontrolled casc, cxcursions of the PSD increment are indicated at 20 to $25 \mathrm{~km}$ in each of these directions. 


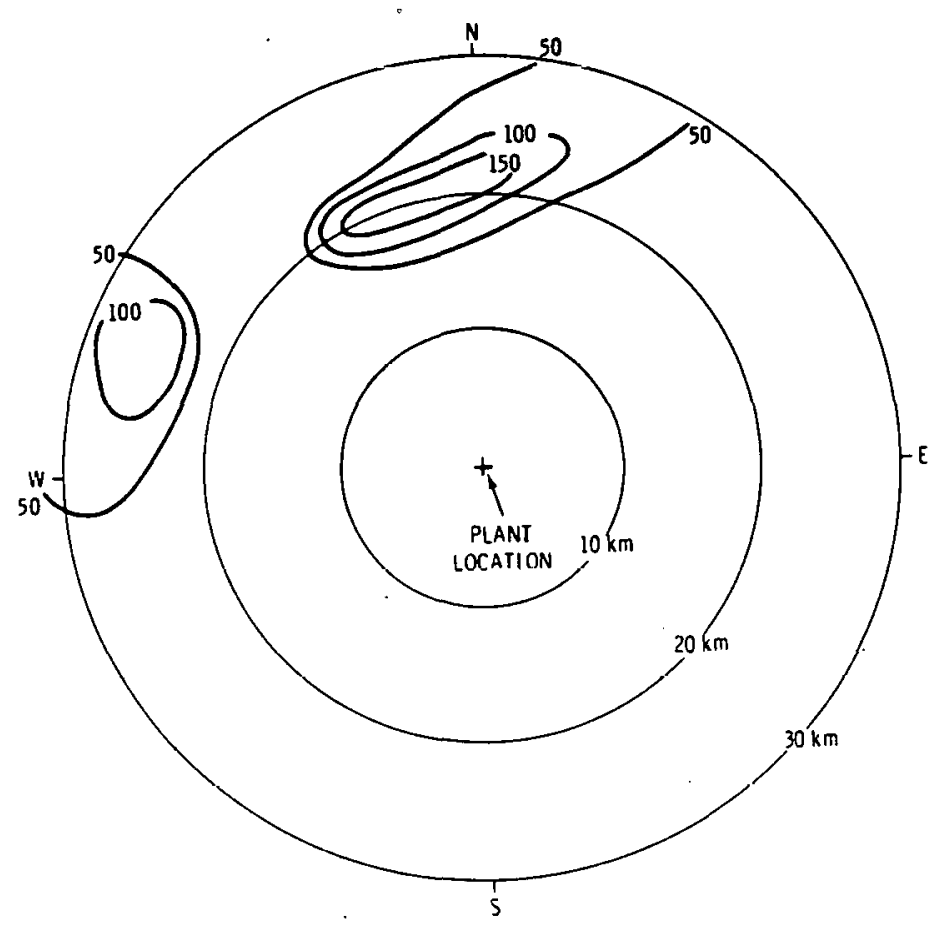

FIGURE 7. Maximum 24-hr Average $\mathrm{SO}_{2}$ Concentrations $\left(\mu \mathrm{g} \mathrm{m}^{-3}\right.$ )

Background $\mathrm{SO}_{2}$ concentrations in the Cook Inlet are low. For example, total $\mathrm{SO}_{2}$ emissions from the Beluga plant if uncontrolled would exceed those of the Air Quality Control Region (EPA 1976). Because of the low background and source contributions, compliance with ambient air quality standards could be expected.

Predicted $\mathrm{SO}_{2}$ concentrations for this screening level analysis indicate that controls under New Source Performance Standards would be sufficient to allow plant compliance to PSD increments. The uncontrolled case, presented for comparison, may or may not be indicated in compliance if more sophisticated path and analysis models are used to remove some of the conservatism of the screening lechmique.

- Three-Hour Average - Sulfur dioxide concentration maxima for the 3-hr averaging period were calculated for comparison to the air quality standard $\left(1300 \mu \mathrm{g} \mathrm{m}^{-3}\right)$ and PSD increments $\left(512 \mu \mathrm{g} \mathrm{m}^{-3}\right)$ using the VALLEY Model. Peak concentrations for neutral stable and unstable atmospheric conditions are given in Table 7, which indicates compliance to the $1300 \mathrm{\mu m}^{-3}$ ambient standard for 
TABLE 7. Sulfur Dioxide 3-hr Average Maximum Concentrations

\begin{tabular}{|c|c|c|c|c|c|}
\hline \multirow{3}{*}{$\frac{\text { Stability }}{\operatorname{Neutral(D)}(a)}$} & \multicolumn{3}{|c|}{ Controlled } & \multicolumn{2}{|c|}{ Uncontrolled } \\
\hline & $\begin{array}{l}\text { Wind speed } \\
\left(\mathrm{ms}^{-1}\right)\end{array}$ & $\begin{array}{l}\text { Conc. } \\
\left(\mu \mathrm{g} \mathrm{m}^{-3}\right)\end{array}$ & $\begin{array}{c}\text { Distance } \\
\quad(\mathrm{km}) \\
\end{array}$ & $\begin{array}{l}\text { Conc. } \\
(\mu \mathrm{g} \mathrm{in}-3)\end{array}$ & $\begin{array}{r}\begin{array}{r}\text { stance } \\
(\mathrm{km})\end{array} \\
\end{array}$ \\
\hline & 6.9 & 120 & 25 & 179 & 30 \\
\hline Unstable (B) & 0.7 & 396 & 10 & 131 & 10 \\
\hline Stable $(E)$ & 0.7 & 265 & 20 & 729 & 20 \\
\hline
\end{tabular}

(a) Pasquill-Gifford classes

both controlled and uncontrolled $\mathrm{SO}_{2}$ cases. Uncontrolled $\mathrm{SO}_{2}$ emission simulations indicated that the PSD increment may be exceeded $20 \mathrm{~km}$ north of the plant with a maximum value of $729 \mathrm{\mu g} \mathrm{m}^{-3}$ and at locations northnorthwest and west of the plant in terrain under stable conditions. The highest predicted concentrations in the controlled case occurred under unstable conditions $10 \mathrm{~km}$ from the $\mathrm{plant}$. Peak impacts in the controlled case are different from the uncontrolled case as a result of the lower plume height expected when scrubbers are utilized.

Background concentrations in the vicinity are expected to be negligible relative to the $3-h r$ standard indicating probable compliance with the ambient concentration standards.

\subsubsection{Total Suspended Particulates}

Total suspended particulate (TSP) concentrations are presented for annual and 24-hr averaging periods:

- Annual Average - A new source in a Class II PSD area must comply with an ambient air quality standard for TSP of $260 \mu \mathrm{g} \mathrm{m}^{-3}$ and a PSD increment of $19 \mathrm{\mu g} \mathrm{m}^{-3}$. The simulated Beluga plant would have no difficulty meeting these standards with a peak concentration of $1.0 \mu \mathrm{g} \mathrm{m}^{-3}$ in the case of the plant under $\mathrm{SO}_{2}$ controls (Figure 8) and $0.9 \mathrm{\mu g} \mathrm{m}^{-3}$ without $\mathrm{SO}_{2}$ controls. The highest impact area is located in the northwest quadrant from Beluga (Figure 8 ), but concentrations were typically below $0.5 \mu \mathrm{g} \mathrm{m}^{-3}$. Relatively high background TSP concentrations can be 


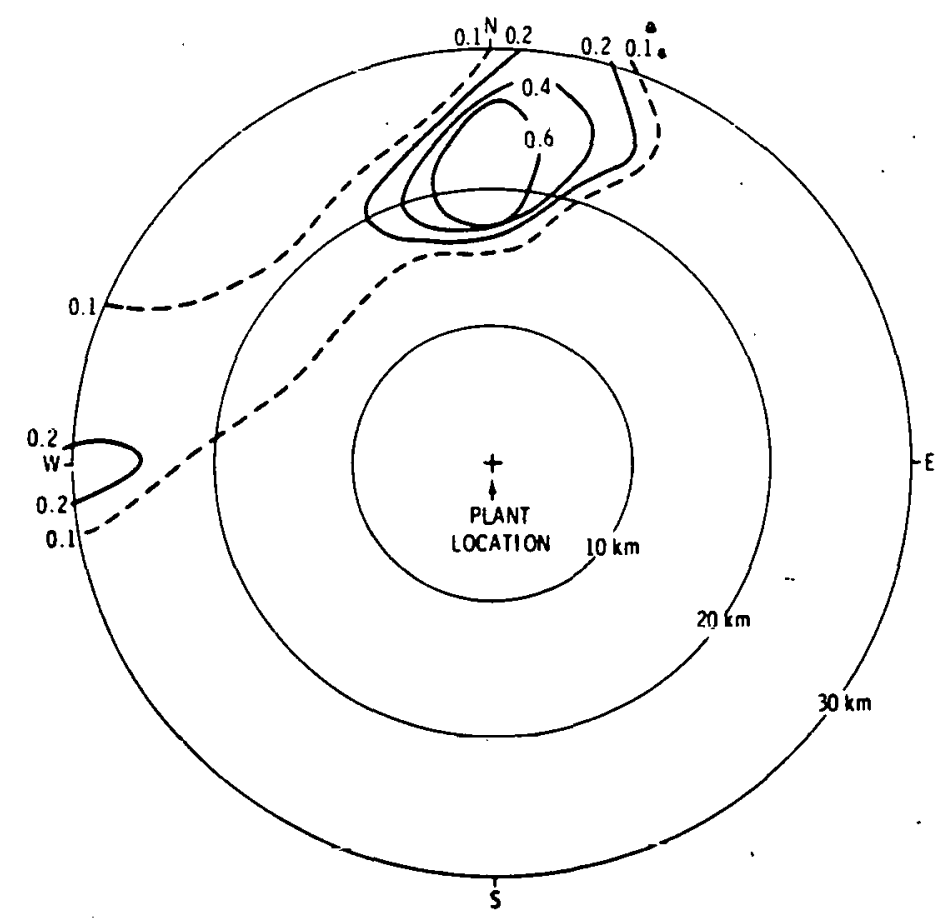

FIGURE 8. Annual Average TSP Concentrations $\left(\mu \mathrm{g} \mathrm{m}^{-3}\right)$ for the Controlled $\mathrm{SO}_{2}$ Emissions Simulations

expected in the area, but their source is primarily fugitive dust $w 1$ th particle sizes much greater than those experienced after controlled coal combustion.

- Twenty-Four-Hour Average - Maximum 24-hr average TSP concentrations were predicted under low wind speed stable atmospheric conditions using the VALLEY model. In general, the case representing controlled $\mathrm{SO}_{2}$ emissions resulted in lower plume rise and higher concentrations. Peak concentrations of $10.8 \mathrm{\mu g} \mathrm{m}^{-3}$ for the uncontrolled case and $8.9 \mu \mathrm{g} \mathrm{m}^{-3}$ for the controlled case are typical of the difference. Figure 9 presents contours of TSP concentrations for the controlled $\mathrm{SO}_{2}$ case. Peak concentrations, as in the annual results, were found west and northwest of the plant site in high terrain. The peak 24-hr concentration was found $20 \mathrm{~km}$ north of the plant.

Air quality data for the Beluga area show excursions from the 24-hr TSP standards as a result of the fugitive dust problem, particularly during the 


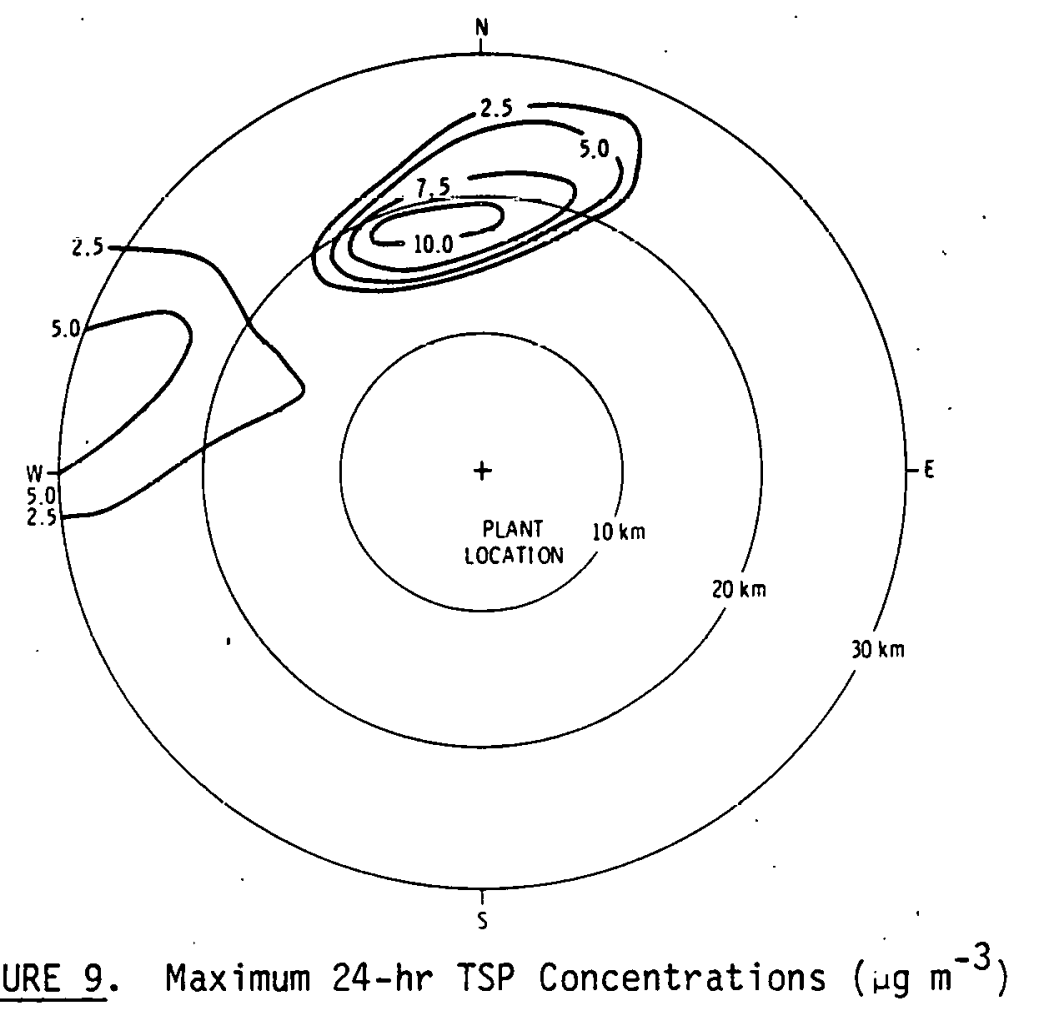

dry summer months (DEC 1977). Predictions of TSP concentrations described above indicate that the plant contribution would be at most $7 \%$ of the $24-\mathrm{hr}$ standard and $24 \%$ of the allowable PSD increments. Concentrations at this level would not be expected to add significan̆tly to the number of standards excursions currently caused by natural fugitive dust.

\subsection{REGIONAL-SCALE IMPACTS}

Regional air quality impacts associated with power plant siting at Beluga are not currently regulated but are of interest. The two potentially important effects are visibility impairment and the acid rain accentuated by the formation of sulfate compounds.

\subsubsection{Visibility}

Sulfur dioxide emissions from the proposed power plant, either controlled or uncontrolled, are relatively low, as are resultant airborne concentrations. Visibility degradation from $\mathrm{SO}_{2}$ emissions results from light scattering by 
sulfate particles formed from $\mathrm{SO}_{2}$ at an average daily rate of approximately $0.5 \% \mathrm{hr}^{-1}$. Simulations are included that provide an estimate of the fractional change in a visual range (visibility) caused by the sulfates formed in the plume.

Latimer et a1. (1978) present an approximation for the formation change in visibility dispersed in the mixed layer. At large distances from the plant where sulfate concentrations become significant this formation change may show the most important case for visibility impairment. The fractional visibility reduction, $F$, is calculated as:

$$
F=\frac{1.5 \dot{Q}_{S_{2}}\left(1-e^{-\lambda t}\right) \cdot a}{3.912 u H}
$$

where the numerator consists of the formation rate of $\mathrm{SO}_{4}$ from $\mathrm{SO}_{2}$ emissions $\left(\dot{\mathrm{Q}}_{\mathrm{SO}_{2}}\right)$ expressed as an exponential decay at a rate $(\lambda)$ over travel time $(t)$, and where $(a)$ is a ratio of the scattering coefficient to the sulfate mass. The denominator includes a constant from the Koschmiëder visual range expression, wind speed $(u)$ and mixed layer depth $(H)$.

Table 8 provides results of simulations using Equation (1) to estimate typical visibility impairment for controlled or uncontrolled peak-load emissions as a function of wind speed and distance. The plume was assumed to be trapped below $1000 \mathrm{~m}$, and a scattering coefficient to sulfate ratio of 0.04 or $\times 10^{-4} \mathrm{~m}^{-1}\left(\mathrm{~g} \mathrm{~m} \mathrm{~m}^{-3}\right)^{-1}$ was used. Calculations were carried out to a distance of $100 \mathrm{~km}$, which is the typical half-width of the air shed. Results indicate that even in the uncontrolled case, visibility degradation greater than $10 \%$ as a result of sulfates is unlikely. This result is probabiy conservative since $\mathrm{SO}_{2}$ and $\mathrm{SO}_{4}$ removal by dry deposition were not included.

\subsubsection{Sulfates}

Secondary formation of sulfates from $\mathrm{SO}_{2}$ emissions was calculated using a simple model that depleted $\mathrm{SO}_{2}$ from the dispersing plume with an exponential decay/conversion expression for $\mathrm{SO}_{2}$ to sulfate: 
TABLE 8. Fractional Decrease in Visual Range

Resulting from Beluga Emissions (\%)

\begin{tabular}{|c|c|c|c|c|}
\hline Distance $(\mathrm{km})$ & \multicolumn{4}{|c|}{ Wind Speed $\left(\mathrm{ms}^{-1}\right)$} \\
\hline Controlled & 0.67 & 2.45 & 4.47 & 6.93 \\
\hline 25 & 0.9 & 0.1 & 0.0 & 0.0 \\
\hline 50 & 1.8 & 0.1 & 0.0 & 0.0 \\
\hline 100 & 3.4 & 0.3 & 0.1 & 0.0 \\
\hline
\end{tabular}

Uncontrolled

$\begin{array}{rrrrr}25 & 3.1 & 0.2 & 0.1 & 0.0 \\ 50 & 6.0 & 0.5 & 0.1 & 0.0 \\ 100 & 11.3 & 0.9 & 0.3 & 0.1\end{array}$

$x_{\text {sulfate }}=x_{\mathrm{SO}_{2}} 1.5\left(1-\mathrm{e}^{-\lambda t}\right)$

where $1.5=$ ratio of $\mathrm{SO}_{4}$ to $\mathrm{SO}_{2}$ molecular weights

$\lambda=$ conversion rate $\left(0.5 \% \mathrm{hr}^{-1}\right)$

$t=$ travel time $(h r)$

$x=$ concentration.

The model contains no plume depletion by deposition. Simulations were made for distances out to the characteristic inlet half-width $(\sim 100 \mathrm{~km})$ and for travel over flat terrain since detailed airflows in the Cook Inlet cannot be determined by available data. Concentrations were calculated for the annual and $24-\mathrm{hr}$ averaging periods.

Annual average sulfate concentrations resulting from plant $\mathrm{SO}_{2}$ emissions were predicted to be undetectable for both the controlled and uncontrolled cases at $100 \mathrm{~km}$ from the plant. Peak $24-\mathrm{hr}$ average concentrations at $105 \mathrm{~km}$ from the $\mathrm{plant}$ were predicted to be approximately $0.1 \mu \mathrm{g} \mathrm{m}^{-3}$ for the uncontrolled case. The controlled $\mathrm{SO}_{2}$ emission case gave negligible sulfate values. The results predicted show the typical case of sulfate concentrations in the Cook Inlet. Concentration predictions for greater distances and for complex flows, such as recirculations and terrain flows, would require more meteorological data than are currently available in concert with a more sophisiticated predictive model. 


\section{THIS PAGE}

\section{WAS INTENTIONALLY LEFT BLANK}




\section{REFERENCES}

Burnham, J. V., ed. 1977. A Preliminary Assessment of the Health and Environmental Effects of Coal Utilization in the Pacific Northwest. PNL-RAP-21, Pacific Northwest Laboratory, Richland, WA.

Costale, D. M. 1979, "New Source Performance Standards for Coal-Fired Power Plants." JAPCA. 29(7):690-692.

Department of Environmental Conservation (DEC). 1977. State of Alaska Proposed Revisions to Air Quality Control Plan. Department of Environmental Conservation, Volume 1 .

Evans, C. D., E. Buck, R. Buffler, G. Fish, R. Forbes, and W. Parker. 1972. The Cook Inlet Environment, A Background Study of Available Knowledge. Prepared for the U.S. Army Corps of Engineers by the University of ATaska under Contract DACW85-72-C-0052.

Latimer, D. A., R. W. Bergstrom, S. R. Hayes, M. K. Liu, J. H. Seinfeld, G. F. Whitten, M. A. Wojcik, and M. J. Hillyer. 1978. The Development of Mathematical Models for the Prediction of Anthropogenic Visibility Impairment. U.S. Environmental Protection Agency Report EPA-450/3/78-110a.

Pacer-Amex, Inc. 1977. Beluga Coal Protect Status Report. Pacer-Amex, Inc., San Francisco, CA.

Rosenberg, H. S., D. S. Ball, B. B. Engdahl, S. G. Bloom, J. M. Genco, A. V. Slack, and J. H. Oxley. 1975. Status of Stack Gas Control Technology (Part 1). EPRI-209, Electric Power Research Institute Report, Palo Alto, CA.

Swift, W. H., R. E. Brown, L. V. Kimmel, M. M. Orgill, P. L. Petersen, W. W. Wadde11. 1974. Geographical Analysis of 0 il Spill Potential Associated with Alaskan 011 Production and Transportation Systems. U.S. Coast Guard Report, DOT-CG 23223-A.

U.S. Environmental Protection Agency. 1976. 1973 National Emissions Report. [PA-450/2-76-007.

U.S. Environmental Protection Agency. 1977. Valley Model Users Guide. EPA-450/2-77-018.

U.S. Environmental Protection Agency. 1978. Guideline on Air Quality. Models. EPA-450/2-78-027 OAQPS No. 1.2-080. 
APPENDIX

EPA VALLEY MODEL

The VALLEY Model is a steady-state, univariate Gaussian plume dispersion model designed for multiple-point and area-source applications. It calculates pollutant concentrations for each frequency designated in an array defined by 6 stabilities, 16 wind directions and 6 wind speeds for 112 program-designated receptor sites on a radial grid of variable scale. The output concentrations are appropriate for either a 24-hr or an annual period as designated by the user. The model contains the concentration equations, the. Pasquil1-Gifford vertical dispersion coefficients and the Pasquill stability classes, as given by Turner. Plume rise is calculated according to Briggs. Plume height is adjusted according to terrain-elevation for stable cases. (a)

Terrain impacts are simulated in the model during stable conditions by decreasing the effective plume height by the difference between stack base elevation and receptor elevation as the plume approaches the terrain. If this difference is less than $10 \mathrm{~m}$, the plume centerline is maintained at $10 \mathrm{~m}$ above the ground. Under neutral and unstable conditions, concentrations are calculated with the plume centerline at the effective plume height above the terrain.

This standardized model also incorporates the following:

- Plume trapping in a mixed layer. Trapping is simulated by multiple plume reflections on the surface and inversion 1id. For long-term simulations, plume decreases above the mixed layer are ignored whereas in the shortterm model, all plumes above the mixing layer are assumed to disperse un iformly in the mixed layer.

- Maximum mixed-layer depth for trapping calculations. This depth is assumed for $60 \%$ of the neutral and unstable events in the year to represent the daytime mixed layer. A value of half of the mixing depth is assigned to the remaining unstable and neutral frequencies to represent nighttime conditions.

(a) U.S. EPA 1977 (Authors' Abstract). 
- Sector averaging of concentrations. Concentrations are calculated over a $22.5^{\circ}$ horizontal sector, and an interpolation is performed to decrease concentrations between the plume centerline of interest and adjacent sector centerlines. 


\section{DISTRIBUTION}

No. of

Copies

OFFSITE

W. W. Burr

DOE Office of Health and Environmental Research Washington, DC 20545

E. S. Burton

DOE Resource Applications and Evaluation

Washington, DC 20545

C. E. Carter

DOE Office of Environmental Research

Washington, DC 20545

Paul Cho

DOE Office of Technology Impacts

Washington, DC 20545

A. A. Churm

DOE Chicago Patent Group

9800 South Cass Avenue

Argonne, IL 60439

Mrs. Ruth Clusen

DOE Assistant Secretary

for Environment

Washington, DC 20545

J. A. Coleman

DOE Office of Technology Impacts

Washington, DC 20545

C. W. Edington

DOE Office of Health and Environmental Research Washington, DC 20545
No. of

Copies

Helen McCammon

DOE Office of Health and Environmental Research Washington, DC 20545

A. J. Goldberg

DOE Office of Technology Impacts

Washington, DC 20545

Dr. Joan Hock

DOE Office of Technology Impacts

Washington, DC 20545

P. W. House

DOE Office of Technology Impacts

Washington, DC 20545

A. B. Joseph

DOE Office of Nuclear

Regulatory Research

Washington, DC 20555

F. G. Lowman

DOE Office of Nuclear

Regulatory Research

Washington, DC 20555

J. Maher

DOE Office of Technology Impacts

Washington, DC 20545

S. P. Mathur

DOE Office of Technology Impacts

Washịngton, DC 20545 
No. of

Copies

W. J. $\mathrm{McCOO} 1$

DOE Office of Environmental Compliance and Overview Washington, DC 20545

D. M. Mont $i$

DOE Office of Technology Impacts

Washington, DC 20545

W. E. Mott

DOE Office of Environmental Compliance and Overview

Washington, DC 20545

$$
\begin{aligned}
& \text { M. Reilly } \\
& \text { DOE Division of Fossil Energy } \\
& \text { Washington, DC } 20545
\end{aligned}
$$

G. J. Rotariu

DOE Office of Technology Impacts

Washington, DC 20545

R. D. Shull

DOE Office of Technology Impacts

Washington, DC 20545

B. W. Wachholz

DOE Office of Technology Impacts

Washington, DC 20545

E. R. Williams

DOE Office of Technology Impacts

Washington, DC 20545

R. W. Wood

DOE Office of Environmental

Research

Washington, DC 20545
No. of

Copies

27 DOE Technical Information Center

S. Ballou

Argonne National Laboratory 9700 South Cass Avenue

Argonne, IL 60439

L. J. Hoover

Argonne National Laboratory

9700 South Cass Avenue

Argonne, IL 60439

P. M. Meier

Building 475

Brookhaven National Laboratory

Upton, NY 11973

W. E. Siri

University of California

Lawrence Berkeley Laboratory

Berkeley, CA 94720

D. Layton

University of California

Lawrence Livermore Laboratory

P.0. Box 808

Livermore, CA 94550

R. K. Lohrding

Los Alamos Scientific Laboratory

P.0. Box 1663

University of California

Los Alamos, NM 87545

R. M. Davis

Oak Ridge National

Laboratory

P.O. Box $X$

Oak Ridge, TN 37830 
No. of

Copies

W. Fulkerson

Oak Ridge National

Laboratory

P.0. Box $X$

Oak Ridge, TN 37830

ALASKA

J. Halterman

State Clearinghouse

Division of Policy Development and Planning

Office of the Governor

Pouch AD

Juneau, AK 99801

J. Lowe 11 Jensen

Public Utilities

Commission

Mackay Building

338 Denali Street

Anchorage, AK 99501

G. Martin

Department of Natural Resources

State Office Building

Pouch M

Juneau, AK 99811

C. Quinlan

Department of Commerce and Economic Development

Mackay Building

338 Denali Street

Anchorage, AK 99501

Col. G. R. Robertson

District Engineer

Alaska District

Corps of Engineers

P.0. Box 7002

Anchorage, AK 99510
No. of

Copies

\section{CALIFORNIA}

R. Doell

U.S. Geological Survey

354 Middlefield Road

Men lo Park, CA 94025

W. Esselman

Electric Power Research Institute

P.0. Box 10412

Palo Alto, CA 94304

L. Henning

Electric Power Research Institute

P.0. Box 10412

Palo Alto, CA 94304

E. Neblet

DOE Federal Energy

Regulatory Commission

U.S. Custom House

San Francisco, CA 94111

R. Uhier

Electric Power Research Institute

P.0. Box 10412

Palo Alto, CA 94304

D. Guss

Bureau of State Planning and Community Affairs

State House

Boise, ID 83720

L. K. Hall

Idaho Energy Office

State House

Boise, ID 83720 
No. of

Copies

IDAHO

M. Neville

Idaho Legislative Council

State House

Boise, ID 83702

K. D. Smith

Public Utilities

Commission

472 W. Washington Street

Boise, ID 83720

R. J. Vissia

Bureau of Reclamation

Federal Building

550 West Fort Street

Boise, ID 83724

R. N. Wise

Bureau of State Planning and Community Affairs

Boise, ID 83720

\section{MONTANA}

J. Binanado

Bureau of Land Management

P.0. Box 30157

Billings, MT 59107

$\underline{\mathrm{OHIO}}$

Ann Rudolph

Battelle Memorial Institute

505 King Avenue

Columbus, $\mathrm{OH} 43201$

\section{OREGON}

Col. H. L. Arnold, Jr.

District Engineer

Portland District

Corps of Engineers

P.O. Box 2946́

Portland, OR 97208
No. of

Copies

R. A. Duncan

Northwest Power Pool

920 S. W. Sixth Avenue

Room 1210

Portland, OR 97204

J. Hoozen

Bonneville Power Administration

P.0. Box 3621

Portland, OR 97208

J. Jaksch

Corvallis Environmental

Research Laboratory

U.S. Environmenta]

Protection Agency

Corvallis, OR 97331

M. Katz

Bonneville Power Administration

P.0. Box 3621

Portland, OR 97208

J. E. Kiley

Bonneville Power Administration P.0. Box 3621

Portland, OR 97208

W. Kvarsten, Director

Conservation and Development Commission

1175 Court Street, N.E.

Salem, OR 97301

D. J. Lewis

Pacific Northwest Utilities Conference Committee

920 S.W. Sixth Avenue

Portland, OR 97204 
No. of

Copies

J. C. Loosii

Bonneville Power Administration P.0. Box 3621

Portland, OR. 97208

F. D. Miller

Oregon Department of Energy

528 Cottage, N.E.

Salem, OR 97310

Maj: Gen. W. E. Peel

Division Engineer

North Pacific Division

Corps of Engineers

210 Custom House

Portland, OR 97209

C. H. Watkins

Bonneville Power Administration

P.0. Box 3621

Portland, OR 97208

\section{WASHINGTON}

F. S. Adair

Washington State Department of Commerce and Economic Development

Olympia, WA 98504

Col. C. J. Alkaire

District Engineer

Walla Walla District

Corps of Engineers

Building 602, City-County

Airport

Walla Walla, WA 99362

L. Bradley

Washington State Energy Office 1000 Cherry

Olympia, WA 98504
No. of

Copies

\author{
W. E. Bruner \\ Forest Policy Project \\ 1-A3600 Main Street \\ Vancouver, WA 98664 \\ L. E. Coate \\ U.S. Environmental Protection \\ Agency \\ 1200 Sixth Avenue \\ Seattle, WA 98101 \\ H. G. Curtis \\ Public Power Council \\ P.0. Box 1307 \\ Vancouver, WA 98660 \\ H. C. Elmore \\ Pacific Northwest Utilities \\ Conference Committee
}

P.0. Box 1231

Wenatchee, WA 98801

M. H. Karr

Pacific Northwest River Basins Commission

1 Columbia River

P.0. Box 980

Vancouver, WA 98660

N. Lewis

Office of Program Planning and Fiscal Management

State Planning Division

House Office Building

01 ympia, WA 98504

B. Pearson

RIS Library

Department of Ecology

Olympia, WA 98504

R. Polzin

Energy Facility Site

Evaluation Council

820 East Fifth Avenue

Olympia, WA 98504 
No. of

Copies

J. B. Robertson

DOE, Federal Region $X$

Federal Building, Room 1992

915 Second Avenue

Seattle, WA 98174

E. T. Shaw

Utilities and Transportation Commission

Highways-Licenses Building

OTympia, WA 98504

M. Walsh

Department of Ecology

State of Washington

0.7 ympia, WA 98504

ONSITE

DOE Richland Operations office

P. W. Gottschalk

H. E. Ransom
No. of

Copies

Pacific Northwest Laboratory

W. J. Bair

R. L. Drake

C. E. Elderk in

R. K. Hadlock

D. L. Hessel (10)

R. E. Kerns

G. B. Long (2)

D. J. McNaughton (5)

W. F. Sandusky

W. H. Swift

R. K. Woodruff

Economics Library (5)

Publishing Coordination (2)

Technical Information Files (5)

Human Affairs Research Center

J. A. Hebert

S. M. Nealey 